\title{
Why Ukraine, Romania and Kazakhstan have been outperformed by Russia and Poland
}

\begin{abstract}
Ukraine has been economically outperformed by Russia, Kazakhstan, Poland and Romania, and is currently suffering from a significant political and economic crisis. However, Romania and Kazakhstan have, in several ways, also been outperformed by Russia and Poland, and this article aims to understand why. The data point to specific policies and the establishment of strong institutions and basic rights, as well as the level of integration with the international economic system. Countries which have been able to stabilise their exchange rates have also done significantly better, while those which have been able to put strong institutions in place and guarantee private property rights have been able to attract foreign investors and establish meaningful trade relationships. Economic performance is not pre-determined by natural resources but can actually be shaped by wise political and economic leadership. Outside political influences, strong institutions and important reforms appear to be far more relevant to economic success than the presence of 'black gold'.
\end{abstract}

Keywords: Ukraine, Russia, Kazakhstan, Poland, Romania, economic development, natural resources, democratisation, transformation, shock therapy, crisis, strong institutions, currency stability, integration, private property rights, corruption

\section{Introduction}

During the past twenty years, some eastern European and central Asian countries have outperformed others. Namely, Russia and Poland have achieved higher GDP per capita than Ukraine, Romania and Kazakhstan. ${ }^{1}$ Ukraine's current political crisis can largely be attributed to its poor level of economic development. Hence, it could be argued that a country's economic success depends on its ties with other countries (through stable exchange rates), as well as its ability to establish strong institutions and guarantee basic rights and its willingness to open up to the global economic system.

A brief assessment of current economic conditions in Russia, Poland, Ukraine, Romania and Kazakhstan

Figure 1 portrays comparative GDP per capita figures for the five countries under examination in our study, using World Bank data cited in the above footnote.

1 World Bank GDP per capita (current US\$) http://data.worldbank.org/indicator/NY.GDP.PCA P.CD/countries [last accessed 2 March 2014]. 


\section{Figure 1 - GDP per capita (current US\$)}

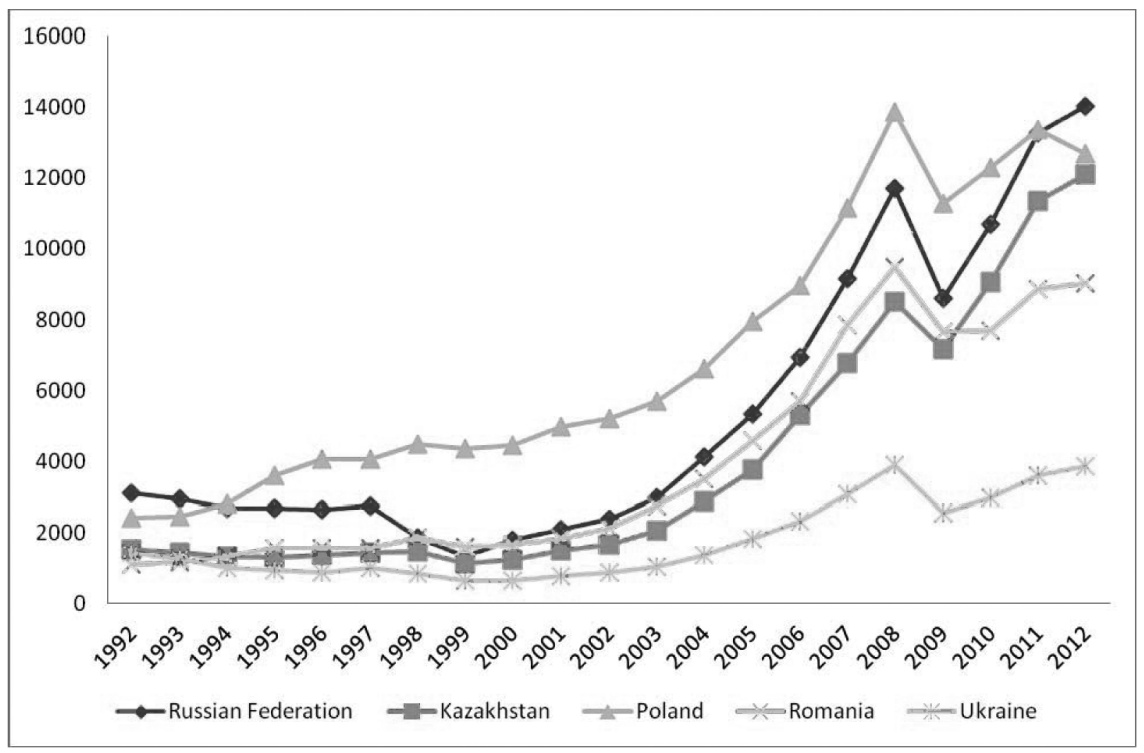

Russia has a GDP per capita of $\$ 18100^{2}$ with a real growth rate of $1.3 \%$ and a labour force of 75.29 million. Most of its GDP is produced by the services sector (58.3\%), while approximately one-third derives from industry $(37.5 \%)$ and the smallest portion from agriculture (4.2\%). It has an unemployment rate of $5.8 \%$ while $13.1 \%$ of the country's population lives below the poverty line. ${ }^{3}$ Purchasing Power Parity Converted GDP per capita (the Laspeyres Index) continuously decreased from 1990 until the end of Yeltsin's rule in 1999, when it reached a historical low of 7,713.8 before subsequently starting to grow, reaching $15,062.24$ in $2010 .^{4}$

This data reflects the economic crisis that Russia had to deal with during the 1990s and also shows how Putin has been able to restore the country.

Poland has outperformed Russia in terms of GDP per capita (\$21 100), with a growth rate of $1.3 \%$, but also has a higher unemployment rate $(13.5 \%)$, although its labour force is only 18.922 million. Some $10.6 \%$ of Poland's population lives below the poverty line. The country's GDP composition is dominated by the services $(57 \%)$ and the industry $(30.2 \%)$ sectors, whereas the agricultural sector makes up $12.9 \%$ of

2 All figures in this section are for 2013, unless otherwise stated.

3 CIA The World Factbook https://www.cia.gov/library/publications/the-world-factbook/geos/r s.html [last accessed on 28 February 2014].

4 Heston, Alan, Robert Summers and Bettina Aten (2012) Penn World Table Version 7.1 Center for International Comparisons of Production, Income and Prices at the University of Pennsylvania, July (refers to 2005 International Dollar per Person). 
Poland's overall GDP. ${ }^{5}$ Poland's Laspeyres Index grew continually between 1990 $(7,627.43)$ and 2010 (16,700.90). By 1999, Poland had outperformed Russia, reaching an Index of 10,818.40. However, due to its massive natural resources and Vladimir Putin's economic policies, Russia has been able to outperform Poland (in terms of growth rates) during the $2000 \mathrm{~s}$.

Compared to Russia and Poland, Ukraine has done poorly. The country has a GDP per capita of $\$ 7400$, with a real growth rate of $0.4 \%$ and a labour force of 22.19 million. Most of its GDP derives from the services (60.5\%) and the industry $(29.6 \%)$ sectors, but the country's economy is also based, to some extent, on agricultural products (9.9\%). It has an unemployment rate of $8 \%$, while $24.1 \%$ (2010 est.) of the country's population lives below the poverty line. ${ }^{6}$ Between 1993 and 1997, the country's Laspeyres Index had decreased from 5,248.8 to 3,391.52 before subsequently starting to increase and reaching a level of 7,047.71 in 2010. Hence, Ukraine has been outperformed by Russia, Kazakhstan, Romania and Poland. ${ }^{7}$

Kazakhstan has done better than Ukraine but worse than Russia and Poland. It has a GDP per capita of $\$ 14100$. Most of its GDP derives from the services (56.9\%) and the industry $(37.9 \%)$ sectors, whereas its agricultural sector is relatively small $(5.2 \%)$ in terms of GDP. It has an unemployment rate of $5.3 \%$ but just $8.2 \%$ (2010 est.) of the population lives below the poverty line. ${ }^{8}$ Its Laspeyres Index decreased between 1993 $(5,938.13)$ and $1998(4,348.81)$, whereupon it recovered quickly, reaching a level of $12,304.91$ in $2010 .{ }^{9}$ Similar to Russia, Kazakhstan suffered economic decline during the 1990s but has been able to recover quickly due to its massive natural resources.

Last but not least, it could be stated that Romania has done worse than Poland, Russia and Kazakhstan but better than Ukraine. Romania has a GDP per capita of $\$ 13500$, which is composed of $10.8 \%$ in the agricultural sector, $37.4 \%$ in industry and $51.8 \%$ in services. Its unemployment rate is relatively low $(4.8 \%)$, but it must be highlighted that $22.2 \%$ (2011 est.) of the country's population lives below the poverty line. ${ }^{10}$ Its Laspeyres Index was relatively constant throughout the 1990s, but increased significantly after the country became a member of the European Union. ${ }^{11}$

The distribution of GDP across the sectors is quite similar in all of these countries, but GDP per capita and the percentage of population living below the poverty line display important differences. Additionally, growth rates in terms of the Laspeyres Index differ in a significant way. Hence, the latter three indicators have been chosen in order to assess each country's economic development. It could, therefore, be said that Poland has outperformed Russia and Kazakhstan during the 1990s but not during

5 CIA The World Factbook https://www.cia.gov/library/publications/the-world-factbook/geo s/pl.html [last accessed on 28 February 2014].

6 ibid.

7 Heston et al, op. cit.

8 CIA The World Factbook https://www.cia.gov/library/publications/the-world-factbook/geo s/kz.html [last accessed on 28 February 2014].

9 Heston et al. op. cit.

10 CIA The World Factbook https://www.cia.gov/library/publications/the-world-factbook/geo s/ro.html [last accessed on 28 February 2014].

11 Heston et al. op. cit. 
the 2000s. Romania has done worse than Poland, Kazakhstan and Russia but has been able to catch up significantly after having become a member of the European Union. Ukraine has done worse than all of these countries.

The following sections of this article offer possible explanations for the differences in economic development, with an emphasis put on aspects of the international political economy.

\section{Geographic and cultural aspects}

Some of the countries have been more fortunate in terms of natural resources than others. For instance, income from total natural resources in Russia made up 29.8 per cent of the country's GDP in 2008. This number decreased to 18.9 and 19.9 per cent in 2009 and 2010 respectively, ${ }^{12}$ but the heavy stimulation of Russia's economic growth by the export of natural resources cannot be ignored. The same is true for Kazakhstan. In 2008, 36.8 per cent of the country's GDP was made up of income from total natural resources. The percentage decreased to 27.6 in 2010 but, again, it cannot be denied that the export of these resources has supported the country's economic recovery. ${ }^{13}$

On the other hand, those countries that have been economically outperformed did not have the natural resources to finance economic growth. Romania, for instance, saw income from total natural resources of 3.3\% of GDP in 2008 and just $2.2 \%$ in 2010 . This is certainly not enough to launch major economic reforms and stimulate growth. ${ }^{14}$ Ukraine had income from total natural resources, in terms of contribution to GDP, of 5.1 per cent in 2008 and 2.9 per cent in 2010 . However, natural resources are not the only determining factor since Poland, which has outperformed its peers in many ways, had income from total natural resources of just 1.0 per cent of GDP in both 2008 and $2010 .{ }^{15}$ Hence, it could be argued that natural resources are not a prerequisite for economic growth, but that they might help to compensate for weaknesses, such as a lack of strong institutions.

Due to their geographic location, some of the countries have been more heavily influenced by western democracies than others. For instance, Poland has a $456 \mathrm{~km}$ long land border with Germany. ${ }^{16}$ Its vicinity to countries like Germany, Austria and Switzerland has facilitated the adoption of capitalist ideologies. Poles had directly observed other nations' success with free markets. Hence, when Poland's leaders suggested heavy reforms, such as the Balcerowicz Plan, which were comparable to Yeltsin's shock therapy, Poles were willing to make sacrifices.

12 Estimates based on sources and methods described in World Bank (2011) The Changing Wealth of Nations: Measuring Sustainable Development in the New Millennium http://data. worldbank.org/indicator/NY.GDP.TOTL.RT.ZS.

13 ibid.

14 ibid.

15 ibid.

16 CIA The World Factbook https://www.cia.gov/library/publications/the-world-factbook/geo s/pl.html [last accessed on 28 February 2014]. 
In 1995 , only $25 \%$ of the Polish population approved of the previous communist regime. ${ }^{17}$ Meanwhile, their Russian counterparts remained more sceptical of economic reforms. Perestroika had caused food shortages and Soviet propaganda had shaped the population's ideas about economics for decades. ${ }^{18}$ Russians were certainly looking both east and west for political guidance. Someone living in Siberia might have related more to China (where communism was still in place) ${ }^{19}$ than to Germany. The same was more or less true for Ukraine, Romania and, especially, Kazakhstan. These countries were geographically remote from western democracies and hence found it more difficult to identify themselves with democratic ideals. Russia was struggling with socialist movements that fought against the restoration of capitalism. ${ }^{20}$ In $1998,72 \%$ of the Russian population still approved of the previous communist regime. ${ }^{21}$ Even in 2009 , only $57 \%$ of the Russian population believed that their country needed democracy. Even more interestingly, $73 \%$ of the Russian population believed that Russian democracy would not have to copy the western model. ${ }^{22}$ However, one also needs to consider that Russia has economically outperformed Romania, a country which is far less remote from western democracies. By 1995, only $28 \%$ of Romania's population approved of the previous communist regime. ${ }^{23}$

Hence, it could be stated that geographic location and openness towards western ideologies might be helpful first indicators when assessing a country's economic development, a profound analysis can certainly not be limited to such superficial factors.

\section{Meaningful reforms}

Geographic location is not the only determining factor; one needs to look at economic reforms. Following the downfall of the Soviet Union and Gorbachev's perestroika and glasnost, many eastern European countries followed the IMF's recommendations and implemented a policy known as 'shock therapy'. In Russia, Boris Yeltsin redistributed wealth through his two waves of privatisation. Powerful oligarchs were able to take advantage of these programmes and seize large parts of the state's wealth. ${ }^{24}$ This caused popular discontent and economic depression. Ultimately, Yeltsin was forced to step down.

17 Diamond, Larry How People View Democracy: From Public Opinion Surveys in Four Regions Stanford University available at: http://www.stanford.edu/ ldiamond/papers/howPeo pleViewDem.pdf [last accessed on 12 April 2013].

18 Sergi, Bruno S. (2009) Misinterpreting Modern Russia - Western Views of Putin and His Presidency Continuum International Publishing Group: New York.

19 Communism in China available at: http://www-cs-faculty.stanford.edu/ eroberts/cs181/ projects/communism-computing-china/china.html [last accessed 6 February 2013].

20 Krausz, Tamas (2007) 'Perestroika and the redistribution of property in the Soviet Union: political perspectives and historical evidence' Contemporary Politics 13(1): 3-36, March.

21 Diamond, op. cit.

22 Levada Analytical Center Russian Public Opinion 2009 available at: http://www.levada.ru/ sites/en.d7154.agava.net/files/Levada2009Eng.pdf [last accessed 12 April 2013].

23 Diamond, op. cit.

24 Sergi (2009) op. cit. 
Poland developed a reform package known as the Balcerowicz Plan which helped it to implement shock therapy more effectively than Russia, Ukraine, Romania and Kazakhstan. The Balcerowicz Plan was divided into ten separate acts, namely:

1. Act on Financial Economy Within State-Owned Companies

2. Act on Banking Law

3. Act on Credits

4. Act on Taxation of Excessive Wage Rises

5. Act on New Rules of Taxation

6. Act on Economic Activity of Foreign Investors

7. Act on Foreign Currencies

8. Act on Customs Law

9. Act on Employment

10. Act on Special Circumstances for Laying-Off an Employee..$^{25}$

In order to achieve long-term economic development and GDP growth, the country's economy had to open up to the rest of the world. This could only be achieved by stabilising the exchange rate. ${ }^{26}$ Thomas Oatley noted:

The sole purpose of the international monetary system is to facilitate international economic exchange. $^{27}$

Once the exchange rate had been stabilised, the country could have started to engage in trade with other countries, attract foreign investment and improve its bargaining position on a global level. In order to be able to stabilise the exchange rate, inflation had to be targeted at a relatively low level.

The exchange rate is the price at which one currency is exchanged for another. A fall in the exchange rate will increase demand and make the internationally-traded sector relatively more attractive compared to the domestic sector and will therefore tend to cause a redirection of resources in its favour. Furthermore the exchange rate is an important component of the price mechanism. ${ }^{28}$ Obviously, exchange rate stability is extraordinarily important in order to ensure long-term economic stability. A volatile exchange rate would result in shocks for the economy and, hence, frighten foreign investors. Direct foreign investment provides an important stimulus for economic growth.

It could be argued that the entire Balcerowicz Plan was designed in order to integrate Poland into world markets. A superficial analysis might consider that most of the reforms were targeted at domestic issues, such as unemployment, but a more sophisticated approach would conclude that the overwhelming majority of the acts was relevant from an international point of view. For instance, the Act on Taxation of Excessive Wage

25 Balcerowicz, L Socjalizm. Kapitalizm. Transformacja. Szkice z przelomu epok available at: http://czytelnia.pwn.pl/pdf/balcerowicz_3.pdf [last accessed 9 February 2013].

26 Miller, James R (1994) 'The Failure of Shock Therapy’ Problems of Post-Communism 41(5): 21, September/October.

27 Oatley, Thomas (2005) International Political Economy Second Edition, Pearson Education.

28 Bannock, Graham and R. E. Baxter Penguin Dictionary of Economics revised and updated edition, Penguin Reference Library. 
Rises was not a purely domestic issue. Workers usually live and work within the boundaries of one single country, but their wages are relevant from an international perspective since they have a significant impact on inflation rates and, hence, exchange rates and currency convertibility. If wages increase, demand goes up and prices increase. If inflation rates rise, the exchange rate suffers. Therefore, it could be argued that the Act on Taxation of Excessive Wage Rises was in support of the Act on Foreign Currencies, and indeed of global economic integration.

The important goal of global economic integration was further pursued by the Act on Economic Activity of Foreign Investors, which delivered incentives for the import of foreign capital. Obviously, this Act would not have made any sense without the Act on New Rules of Taxation, since very few foreign investors would have tolerated an unfair tax system. The Act on Customs Law was essential for complying with international trade agreements and creating a competitive domestic market by eliminating severe injustices. Hence, all three of these acts were aimed at facilitating international trade and attracting foreign investors.

The acts on Employment and on Special Circumstances for Laying-off an Employee appear to be exclusively domestic issues. However, they were aimed at controlling the consequences of monetary manoeuvres aimed at controlling inflation and the exchange rate. Inflation can be reduced in several ways. The Polish government decided to cut the budget deficit, tighten central bank credit and raise market interest rates. If banks receive less money from the central bank, they are forced to increase interest rates. If interest rates are raised, both citizens and enterprises borrow less money from banks (borrowing is only convenient if the cost of capital is inferior to the potential return). The trade-off of this policy is a domestic problem: the public sector, private enterprises and ordinary citizens have less money to spend. This provokes stagnation or even recession. It did allow Poland significantly to reduce inflation and attract foreign investors, ${ }^{29}$ but it also caused unemployment rates to increase. Balcerowicz appears to have been aware of this trade-off and prepared his country for the sacrifices that had to be made in order to achieve economic integration.

At the same time that Poland was getting ready for international trade and foreign investment, Russia was facing monetary chaos. Multiple central banks were issuing the same currency. The monetary expansion in Ukraine was even worse. ${ }^{30}$ Kazakhstan, in contrast, was able to pursue an independent monetary policy. It did have to overcome credibility issues, but it was able to reduce inflation from $2,984.5 \%$ in 1992 to $5.9 \%$ in 2002 due to a tight monetary policy and heavy restrictions on the financing of the state's budget deficit. ${ }^{31}$ Romania's attempts to stabilise exchange rates failed completely, since

29 Sachs, Jeffrey Shock Therapy in Poland: Perspectives of Five Years delivered at University of Utah, 6/7 April 1994, available at: http://tannerlectures.utah.edu/lectures/documents/sac hs95.pdf [last accessed 18 February 2013].

30 Watkins, Thayer Hyperinflation in the Ukraine in the 1990s available at: http://www.sjsu.e du/faculty/watkins/ukraineinfl.htm [last accessed 18 February 2013].

31 Larsson, Johan Fredborn The Transition in Kazakhstan. From Command to Market Econo$m y$ available at: http://www.nek.lu.se/Publ/mfs/199.pdf [last accessed 21 February 2013]. 
the Romanian central bank's policies were mainly based upon rhetoric and not action. ${ }^{32}$

It could be argued that adopting policies which favoured a stable currency and permanent integration into the international system is essential for economic success. Kazakhstan and Russia could afford the luxury of adopting chaotic policies as their integration was only a matter of time. Due to their enormous natural resources, the international community had a strong interest in creating trade relations with them. In fact, Russia is the world's largest oil exporter. Consequently, they were able to recover quickly from their mistakes. They are still lagging behind Poland, but their massive natural resources will allow them to further integrate into the international community. Other less fortunate countries, such as Romania and Ukraine, which had adopted the wrong policies and do not have significant natural resources, are currently paying a heavy price.

\section{History repeats itself}

Another powerful argument that simply cannot be ignored is that the establishment of strong institutions favours economic development. This is particularly relevant from an international perspective since strong institutions create stability and credibility among nations. These are two important prerequisites for international peace and security but also for foreign investment and simple trade relationships. If a global company considers making significant capital investment in a country, it needs to be convinced that the country is not facing excessive risks, such as a return to communism, seizure of private property or political turmoil. Even if this global company is only considering exporting goods to a foreign country, it needs to be sure that its trade partner will pay for these products. If institutions are weak, and suing someone is excessively time-consuming or expensive, if not impossible, the foreign company will have to pay in advance. For newly-established companies in particular, this could be a cash-flow problem. Poland quickly established very strong institutions, whereas Ukraine, Romania, Russia and Kazakhstan are known to be very corrupt. ${ }^{33}$ Romania made some progress when it became part of the European Union. Russia and Kazakhstan are investing the revenues from exporting their natural resources, the state is becoming more and more powerful and law-free zones are diminishing. Ukraine has very weak private property rights, is excessively corrupt and known for its weak institutions.

The differences in economic development in eastern Europe and central Asia emphasise the relevance of domestic political institutions. One could have hoped that humanity had learned from the experience of the former colonies in the Americas and the Caribbean. Some countries, such as Mexico, Peru and Barbados, had initially been far better-off than their counterparts (present-day USA and Canada) but they have not been able to achieve long-term economic growth. This is mainly attributed to a lack of strong institutions. Sokoloff and Engerman suggest that highly unequal societies, due

32 Gabor, Dana (2013) Monetary Policy in Romania. Changing Rhetoric Not Practice available at: http://bbs.mis.brighton.ac.uk/eaces/papers/5b1.pdf [last accessed 21 February 2013].

33 Transparency International 2013 Corruption Perceptions Index available at: http://cpi.trans parency.org/cpi2013/results/ [last accessed 22 February 2014]. 
to the importation of slaves or the plundering of indigenous silver reserves, allowed the ruling class to impede the establishment of strong institutions. In contrast, the northern colonies did not have large silver deposits or soil suitable for large tenure. Small farmers developed into more equal societies and favoured the establishment of political institutions in order to protect private property rights. ${ }^{34}$ Niall Ferguson supports this argument and suggests that the rule of law, constitutions and civil society are relevant to a country's economic development. He argues that private property can create plurality beyond state control and thereby establish freedom. Furthermore, he praises secular institutions for establishing norms for land ownership. ${ }^{35}$

With Moscow today having more billionaires than Manhattan, ${ }^{36}$ one could argue that private property rights are being respected in modern-day Russia. Generallyspeaking, business people and foreign investors in Russia do have a solid chance that their private property rights will be respected, since Yeltsin established the legal basis for strong institutions during the late $1990 \mathrm{~s}^{37}$ while Putin has, since then, fortified and further expanded these state bodies. Considering Russia's economic development, one could argue that, during times of weak institutions, mainly the $1990 \mathrm{~s}$, the country was facing economic hardship. Subsequently, the growth and greater meaningfulness of the institutions has seen significant improvements in Russia's economy.

However, it should not be neglected that Russia still ranks in $127^{\text {th }}$ place in the 2013 Corruption Perceptions Index. ${ }^{38}$ Hence, one could argue that Russia's massive natural resources have allowed the country to stimulate economic growth without establishing very strong institutions and fully securing private property rights. The upshot is that Russia will have to improve its institutions and private property rights further in order to ensure long-term economic development and stability. Eventually, the country will run out of 'black gold' and other resources, and will need as a result to rely upon a stable and diversified economic system. In conclusion, it could be said that both Putin's and Medvedev's efforts toward establishing law and order in Russia have been very successful, and have significantly contributed to the country's economic growth.

This importance of strong institutions can be further supported by analysing Poland's economic development. Even during the early 1990s, the country emphasised the importance of strong institutions and the rule of law. The country is still not living up to its full potential, since the commercial court system is inefficient and corruption fosters economic injustice, ${ }^{39}$ but private property rights are secure. The economic convergence between Poland and Russia could be tied to both countries' progress regarding

34 Sokoloff, Kenneth L and Stanley L. Engerman (2010) 'History Lessons: Institutions, Factor Endowments, and Paths of Development in the New World' in Jeffry A. Frieden, David A. Blake and J. Lawrence Broz International Political Economy-Perspectives On Global Power and Wealth Fifth Edition, W.W. Norton \& Company.

35 Ferguson, Niall Civilization - The West and the Rest Chapter 3.

36 Sergi (2009) op. cit.

37 Colton, Timothy J (2008) Yeltsin - A Life Basic Books: New York.

38 Transparency International 2012 Corruption Perceptions Index available at: http://cpi.trans parency.org/cpi2012/results/ [last accessed 22 February 2013].

39 CIA The World Factbook https:/www.cia.gov/library/publications/the-world-factbook/geo s/pl.html [last accessed on 28 February 2014]. 
private property rights and strong institutions. Russia was lagging behind during the 1990s, but its significant natural resources have helped it catch up with the Poles and ultimately outperform them, in many ways. However, that Poland could not draw upon large oil and gas fields to foster its economic growth suggests that solid rights and institutions might be more important than an abundance of raw materials. Poland ranks in $38^{\text {th }}$ place in the 2013 Corruption Perceptions Index. ${ }^{40}$ This suggests that there is still a need for improvement.

Kazakhstan is lagging behind both Russia and Poland regarding economic development and private property rights. There are strong limitations on land ownership by foreign citizens and non-Kazakh legal entities. ${ }^{41}$ Furthermore, the Kazakh government is promoting Kazakh as the national language, which serves to alienate foreign investors. In particular, Russians are targeted by these policies and private properties have been arbitrarily seized..$^{42}$ This lack of law and order is reflected in the country's level of economic development. Kazakhstan has been doing better than Ukraine and Romania due its massive natural resources, but will have to establish strong institutions in order to secure long-term economic growth. Kazakhstan ranks in $140^{\text {th }}$ place in the 2013 Corruption Perceptions Index. ${ }^{43}$ However, it should also be mentioned that Kazakhstan has made significant process during the last two decades and is likely to achieve massive economic growth within the next twenty years.

Once again highlighted by the recent protests, Ukraine has a complete lack of strong institutions, which reflects its poor economic development. Ukraine has a history of selective prosecutions. Yulia Tymoshenko, Ukraine's former prime minister, has been the authorities' favourite target. A country that suppresses political opponents by selectively prosecuting them loses credibility and this leads to suspicion among foreign investors. Other countries also condemn selective prosecution. Private property rights in Ukraine used to be reasonably secure prior to the protests in February 2014, but the country's corrupt and subjective legal system causes instability and concern. For instance, prostitution is illegal in Ukraine. However, massage salons which offer sexual services and pay unofficial fees to the local police are tolerated. This, in part, explains why Ukraine has been economically outperformed. Ukraine has the highest level of corruption among all the countries encompassed by this article and is placed in 144th position in the 2013 Corruption Perceptions Index. ${ }^{44}$

Last, but not least, it needs to be mentioned that Romania has benefited significantly from the European Union. The EU has helped Romania fortify its institutions and guarantee private property rights. However, corruption levels are still extraordinarily

40 Transparency International 2013 Corruption Perceptions Index available at: http://cpi.trans parency.org/cpi2013/results/ [last accessed 22 February 2014].

41 Doing Business in Kazakhstan available at: http://www.bakermckenzie.com/files/Uploads/ Documents/Supporting\%20Your\%20Business/Global\%20Markets\%20QRGs/DBI\%20Kaz akhstan/bk_dbi_kazakhstan_propertyrights.pdf [last accessed 22 February 2012].

42 Interview with Xenia, daughter of a Russian businessman in Kazakhstan, on 14 February 2013 in Milan, Italy.

43 Transparency International 2013 Corruption Perceptions Index available at: http://cpi.trans parency.org/cpi2013/results/ [last accessed 22 February 2014].

44 ibid. 
high and the system is known for being ineffective. A parallel can be drawn with Ukraine. Prostitution is illegal, but tolerated. Once again, the lack of law and order is reflected in the country's economic development. This is further supported by the Transparency International 2013 Corruption Perceptions Index, where Romania is ranked $69^{\text {th }} .45$

Integration with the international system

Romania's financial system is strongly integrated with the rest of the world. The country's supervisory authorities have implemented multiple EU directives, as well as the recommendations of the 2003 FSAP. However, Romania's banks are suffering from the country's weak currency. The depreciation of the leu, in combination with harsh economic conditions, turn potential stress tests into a concern for the country's financial institutions. In this regard, the strong interdependence of the global financial system, and with many Romanian banks being owned by foreign financial institutions, could turn out to be a major advantage. Other countries would not benefit from pushing Romanian banks into bankruptcy and are thus likely to agree to refinance them. However, in order to ensure the success of this endeavour, further improvements in the co-ordination of the country's banking supervision do need to be made. ${ }^{46}$

Despite Romania's financial system being relatively well-developed, these flaws might help to explain why the country has not been able to grow as fast as Poland. Romania might only hold $0.39 \%$ of world trade, but it is ranked among the top 25 countries in terms of trade policy. This suggests that the country's future economic development will benefit from its internationally-integrated trade and financial system.

Poland has also been able to develop a financial system able to compete with the rest of the world. It has been able to establish insurance companies, pensions and investment funds, as well as a wide range of commercial banks. The banking system appears to be stable and well-capitalised. The insurance sector, however, appears to need more consolidation. Securities markets are small, but they operate on a sound basis. Payment and settlement systems tend to be efficient, while domestic money markets operate smoothly. Furthermore, regulation and supervision have been improving continuously. ${ }^{47}$

Poland's financial system could be considered one of the major reasons why the country has been able to ensure long-term economic growth. This is further supported by the country's liberal trade policies. By reducing tariffs, and eventually becoming part of the European Union, the country has been able to improve its trade relationships

45 ibid.

46 International Monetary Fund Romania: Financial Sector Stability Assessment February 2010 available at: http://www.imf.org/external/pubs/ft/scr/2010/cr1047.pdf [last accessed 12 April 2013].

47 International Monetary Fund Republic of Poland: Financial System Stability Assessment available at: http://www.imf.org/external/pubs/ft/scr/2001/cr0167.pdf [last accessed 12 April 2013]. 
significantly. In 2010 , the country held $1.16 \%$ of world trade and was ranked among the top 25 competitors in trade policy (worldwide). ${ }^{48}$

Kazakhstan's banking sector is integrated with the international financial system, for instance through its renowned ATF bank (a former subsidiary of Bank Austria and, thus, Unicredit Group), but it still does not live up to western standards. The existing legislation regarding money laundering and the financing of terrorism illustrates the weakness of the entire system. However, a positive macroeconomic environment has allowed the Kazakhstan banking sector to grow and achieve substantial profits. ${ }^{49}$ Despite Kazakhstan's financial sector making substantial improvements, its trade relationships still have to catch up. The country is currently ranked as the $26^{\text {th }}$ major trading partner of the European Union. ${ }^{50}$

Despite the global financial crisis, the Russian domestic financial system has maintained its stability. Hence, not being too integrated with the global system has turned out to be a competitive advantage during difficult times. However, long-standing governance weaknesses have also prevented the Russian financial system from becoming fair, transparent and competitive. ${ }^{51}$ Despite Russia's financial system still having a long way to go, the country has been able to establish successful trade relationships. For instance, it is ranked as the European Union's third trading partner, following the United States and China. ${ }^{52}$

The Ukrainian financial system is characterised by excessive credit risk in the banking sector. This can, in part, be attributed to inadequate accounting standards in enterprises; these make it difficult accurately to assess information. Regulation and supervision of financial institutions is lagging behind. ${ }^{53}$ Ukraine has slightly better trade relationships than Kazakhstan, but it still has a long way to go. It is currently ranked as the EU's 22nd most important trade partner.

48 World Bank Poland - Trade at a Glance Table available at: http://info.worldbank.org/etool s/wti/docs/Poland_taag.pdf [last accessed 12 April 2013].

49 International Monetary Fund Republic of Kazakhstan: Financial System Stability Assessment - Update - Detailed Assessments and Updates of Financial Sector Standards and Codes available at: https://www.imf.org/external/pubs/ft/scr/2004/cr04338.pdf [last accessed 12 April 2013].

50 European Commission Kazakhstan - EU Bilateral Trade and Trade with the World available at: http://trade.ec.europa.eu/doclib/docs/2006/september/tradoc_113406.pdf [last accessed 12 April 2013].

51 International Monetary Fund Russian Federation: Financial System Stability Assessment available at: http://www.imf.org/external/pubs/ft/scr/2011/cr11291.pdf [last accessed 12 April 2013].

52 European Commission Kazakhstan-EU Bilateral Trade and Trade with the World available at: http://trade.ec.europa.eu/doclib/docs/2006/september/tradoc_113406.pdf [last accessed 12 April 2013].

53 International Monetary Fund Ukraine: Financial System Stability Assessment, including Reports on the Observance of Standards and Codes on the following topics: Monetary and Financial Policy Transparency, Banking Supervision, and Payment Systems available at: http://www.imf.org/external/pubs/ft/scr/2003/cr03340.pdf [last accessed 12 April 2013]. 


\section{Conclusion}

From the late 1980s until today, some eastern European and central Asian countries have been able to outperform their peers economically. A significant divergence in GDP per capita, PPP Converted GDP per capita growth rates (Laspeyres Index) and the percentages of the population living below the poverty line cannot simply be explained by differences in natural resources, such as oil and gas. Compared to Russia and Kazakhstan, Poland has no significant natural resources but was still able to outperform its major competitors until a few years ago. Differences in economic development are due to a country's ability to design and implement meaningful reforms which help to integrate it into the global market. An internationally-integrated trade and financial system tends to favour economic development. Furthermore, strong institutions and solid private property rights tend to be important determinants of economic growth.

Last but not least, a country's openness and willingness to embrace new ideas is a determining factor for economic development after the downfall of communism. Those willing to accept capitalist ideologies were far better off than those who wanted to return to the old Communist system. Ukraine has failed to implement many of the success factors outlined above and is thus today facing a significant political and economic crisis. The Ukrainian government should focus on creating strong institutions and private property rights and look to integrate its trade and financial system with that of the rest of the world.

\section{References}

Balcerowicz, L Socjalizm. Kapitalizm. Transformacja. Szkice z przelomu epok available at: http://czytelnia.pwn.pl/pdf/balcerowicz_3.pdf [last accessed 9 February 2013].

Bannock, Graham and R. E. Baxter Penguin Dictionary of Economics revised and updated edition, Penguin Reference Library.

CIA The World Factbook https://www.cia.gov/library/publications/the-world-factbook/geos/rs.html [last accessed on 28 February 2014].

CIA The World Factbook https://www.cia.gov/library/publications/the-world-factbook/geos/pl.html [last accessed on 28 February 2014].

CIA The World Factbook https://www.cia.gov/library/publications/the-world-factbook/geos/up.html [last accessed on 28 February 2014].

CIA The World Factbook https://www.cia.gov/library/publications/the-world-factbook/geos/kz.html [last accessed on 28 February 2014].

CIA The World Factbook https://www.cia.gov/library/publications/the-world-factbook/geos/ro.html [last accessed on 28 February 2014].

Colton, Timothy J (2008) Yeltsin - A Life Basic Books: New York.

Communism in China available at: http://www-cs-faculty.stanford.edu/ eroberts/ cs181/projects/communism-computing-china/china.html [last accessed 6 February 2013]. 
Diamond, Larry How People View Democracy: From Public Opinion Surveys in Four Regions Stanford University available at:

http://www.stanford.edu/ ldiamond/papers/howPeopleViewDem.pdf [last accessed on 12 April 2013].

Doing Business in Kazakhstan available at: http://www.bakermckenzie.com/files/Uploads/Documents/Supporting\%20Your\%20Business/Global\%20Markets $\% 20 Q R G s / D B I \% 20 K a z a k h s t a n / b k \_d b i \_k a z a k h s t a n \_p r o p e r t y r i g h t s . p d f$ [last accessed 22 February 2012].

European Commission Kazakhstan - EU Bilateral Trade and Trade with the World available at:

http://trade.ec.europa.eu/doclib/docs/2006/september/tradoc_113406.pdf [last accessed 12 April 2013].

Ferguson, Niall Civilization - The West and the Rest Chapter 3.

Gabor, Dana (2013) Monetary Policy in Romania. Changing Rhetoric Not Practice available at: http://bbs.mis.brighton.ac.uk/eaces/papers/5b1.pdf [last accessed 21 February 2013].

Heston, Alan, Robert Summers and Bettina Aten (2012) Penn World Table Version 7.1 Center for International Comparisons of Production, Income and Prices at the University of Pennsylvania, July (refers to 2005 International Dollar per Person).

International Monetary Fund Republic of Poland: Financial System Stability Assessment available at: http://www.imf.org/external/pubs/ft/scr/2001/cr0167.pdf [last accessed 12 April 2013].

International Monetary Fund Republic of Kazakhstan: Financial System Stability Assessment - Update - Detailed Assessments and Updates of Financial Sector Standards and Codes available at: https://www.imf.org/external/pubs/ft/scr/2004/ cr04338.pdf [last accessed 12 April 2013].

International Monetary Fund Republic of Poland: Financial System Stability Assessment available at: http://www.imf.org/external/pubs/ft/scr/2001/cr0167.pdf [last accessed 12 April 2013].

International Monetary Fund Ukraine: Financial System Stability Assessment, including Reports on the Observance of Standards and Codes on the following topics: Monetary and Financial Policy Transparency, Banking Supervision, and Payment Systems available at: http://www.imf.org/external/pubs/ft/scr/2003/cr03340.pdf [last accessed 12 April 2013].

International Monetary Fund Romania: Financial Sector Stability Assessment February 2010 available at: http://www.imf.org/external/pubs/ft/scr/2010/cr1047.pdf [last accessed 12 April 2013].

International Monetary Fund Russian Federation: Financial System Stability Assessment available at: http://www.imf.org/external/pubs/ft/scr/2011/cr11291.pdf [last accessed 12 April 2013]. 
Krausz, Tamas (2007) 'Perestroika and the redistribution of property in the Soviet Union: political perspectives and historical evidence' Contemporary Politics 13(1): 3-36, March.

Larsson, Johan Fredborn The Transition in Kazakhstan. From Command to Market Economy available at: http://www.nek.lu.se/Publ/mfs/199.pdf [last accessed 21 February 2013].

Levada Analytical Center Russian Public Opinion 2009 available at: http://www.levada.ru/sites/en.d7154.agava.net/files/Levada2009Eng.pdf [last accessed 12 April 2013].

Miller, James R (1994) 'The Failure of Shock Therapy' Problems of Post-Communism 41(5): 21, September/October.

Oatley, Thomas (2005) International Political Economy Second Edition, Pearson Education.

Sachs, Jeffrey Shock Therapy in Poland: Perspectives of Five Years delivered at University of Utah, 6/7 April 1994, available at: http://tannerlectures.utah.edu/lectures/ documents/sachs95.pdf [last accessed 18 February 2013].

Sergi, Bruno S. (2009) Misinterpreting Modern Russia - Western Views of Putin and His Presidency Continuum International Publishing Group: New York.

Sokoloff, Kenneth L and Stanley L. Engerman (2010) 'History Lessons: Institutions, Factor Endowments, and Paths of Development in the New World' in Jeffry A. Frieden, David A. Blake and J. Lawrence Broz International Political EconomyPerspectives On Global Power and Wealth Fifth Edition, W.W. Norton \& Company.

Transparency International 2012 Corruption Perceptions Index available at: http:// cpi.transparency.org/cpi2012/results/ [last accessed 22 February 2013].

Transparency International 2013 Corruption Perceptions Index available at: http:// cpi.transparency.org/cpi2013/results/ [last accessed 22 February 2014].

Watkins, Thayer Hyperinflation in the Ukraine in the 1990s available at: http://www.sjsu.edu/faculty/watkins/ukraineinfl.htm [last accessed 18 February 2013].

Watson, R and F. Coleman 'Shock Therapy with Emphasis on Shock' Newsweek 119(2): 28, 13 January 1992.

World Bank Poland - Trade at a Glance Table available at: http://info.worldbank.org/ etools/wti/docs/Poland_taag.pdf [last accessed 12 April 2013].

World Bank GDP per capita (current US\$) available at: http://data.worldbank.org/ indicator/NY.GDP.PCAP.CD/countries [last accessed 2 March 2014].

Estimates based on sources and methods described in World Bank (2011) The Changing Wealth of Nations: Measuring Sustainable Development in the New Millennium http://data.worldbank.org/indicator/NY.GDP.TOTL.RT.ZS. 
Interview with Xenia, daughter of a Russian businessman in Kazakhstan, on 14 February 2013 in Milan, Italy. 